\title{
Legal Implications of State Government's Control over Internally Generated Revenue of Local Government Councils in Oyo State, Nigeria
}

\author{
Grace Abosede Oladele \\ Faculty of Law, Adeleke University, Ede, Osun State, Nigeria \\ Email: abosedeoladele0@gmail.com
}

How to cite this paper: Oladele, G. A. (2020). Legal Implications of State Government's Control over Internally Generated Revenue of Local Government Councils in Oyo State, Nigeria. Beijing Law Review, 11, 899-910.

https://doi.org/10.4236/blr.2020.114054

Received: September 29, 2020

Accepted: December 15, 2020

Published: December 18, 2020

Copyright (อ 2020 by author(s) and Scientific Research Publishing Inc. This work is licensed under the Creative Commons Attribution International License (CC BY 4.0).

http://creativecommons.org/licenses/by/4.0/ (c) (i) Open Access

\begin{abstract}
This paper examines the sources of internally generated revenue of Local Government Councils in Oyo State and shows that the State Government had taken over the high yielding ones. It also examines section 7 of the Local Government Law 2001 (as amended) of Oyo State which empowers the State Government to collect internally generated revenue of Local Government Councils and give them ten percent out of it. It establishes that this provision contradicts section 162 (7) of the Constitution that mandates each State to pay Local Government Councils out of its total revenue. It also shows that the provision is inconsistent with section 4 (1) of the Allocation of Revenue (Federation Account, Etc.) Act which provides that in addition to the allocation made from the Federation Account to Local Government Councils, each State must distribute ten percent of its internally generated revenue among the Local Government Councils in the State. Thus, each State Government is expected to pay ten percent of its internally generated revenue to Local Government Councils in the State and not compel them to pay their internally generated revenue into State coffer, giving them ten percent of it in return. This paper argues that section 7 of the Local Government Law 2001 is unconstitutional and has drastically reduced the income received from internally generated revenue of Local Government Councils, thereby placing them in miserable financial conditions which have retarded their developmental efforts. The paper concludes that internally generated revenue is the live wire of Local Government Councils, therefore, the Local Government Law 2001 (as amended) and other similar laws should be challenged in court and declared null and void. It also recommends autonomy for Local Government Councils so that they can absolutely control their revenue and use it judiciously for the
\end{abstract}


development of their localities.

\section{Keywords}

Local Government Councils, Constitution, Internally Generated Revenue, State Government

\section{Introduction}

The Local Government is the third tier of government and the closest to the people (Samuel, 2016). It is usually vested with power over local affairs which include the power to impose taxes, rates and fees for the purpose of revenue generation (Danjuman \& Zakariyau, 2012).

Over the years in Nigeria, Local Government developmental efforts have suffered a lot of setback due to excessive control of their internally generated revenue by the State Government. This has restricted the fiscal jurisdiction of Local Government Councils. As a result, the financial resources available to them had dwindled and remained grossly inadequate to achieve any meaningful development.

As a tier of government, each Local Government Council is expected to sustain rapid growth and development at the grassroot level, and this can only be actualized through availability of sufficient revenue (Ayogu et al., 2019). Statutorily, Local Government Councils receive revenue from the federation account (section 162 (3) of the Constitution of the Federal Republic of Nigeria), State Government (section 162 (7) of the Constitution of Nigeria and section 4 (1) of the Allocation of Revenue (Federation Account etc. Act) and internally generated revenue (Fourth Schedule to the Constitution of Nigeria)). However, they cannot completely rely on allocation from federation account because it fluctuates depending on the available federal revenue. Also, the $10 \%$ which the State Government is mandated to pay under section 4 (1) of the Allocation of Revenue (Federation Account, Etc.) Act may not be forthcoming on the excuse that the State also needs money to service its expenditure. Thus, internal revenue is the only source of revenue which Local Government Councils can generate and exercise absolute control over to administer the Councils and develop their localities.

However, in Oyo State, over the years the Local Government Councils have not been financially buoyant and are unable to effectively provide the needed services in their areas. This is as a result of the provisions of section 7 of the Local Government Law 2001 (as amended) of Oyo State which mandates Local Government Councils to pay their internally generated revenue into the State Government coffer out of which only ten percent (10\%) is remitted to them. This provision deprives Local Government Councils of substantial internally generated revenue and at the same time, amounts to a deliberate refusal to remit the statutory ten percent of State revenue which must be paid to the Local Government Councils. 
This paper examines the sources of revenue of Local Government Councils in particular, internally generated revenue which is derived from the functions performed by the Councils. It examines the provisions of section 7 of the Local Government Law 2001 of Oyo State which empowers the State Government to pay Local Government Councils ten percent out of the internally generated revenue received from Local Government Councils and asserts that it violates section 162 (7) of the Constitution which provides that State Governments should give Local Government Councils a proportion of its revenue. The Constitution does not empower the State Government to receive internally generated revenue belonging to Local Government Councils. Thus, section 7 of the Local Government Law is unconstitutional, null and void. The paper recommends constitutional autonomy and other measures as ways through which Local Government Councils can have total control over their revenue, in particular, internally generated revenue and be able to foster development at the grassroot level.

\section{Local Government System in Nigeria}

The Local Government is a unit of government in a federal system established by law to exercise political authority through a representative council within a defined area (Otu \& Anam 2019). One of the reasons for establishing Local Government is to enhance rural development.

In Nigeria, the Constitution guarantees the establishment of elected Local Government Councils. Section 7 (1) of the Constitution provides for the existence of democratically elected Local Government Councils and mandates State Governments to ensure their existence under a Law which provides for their establishment, structure, composition, finance and functions.

In Oyo State, the law governing Local Government administration is the Local Government Law, 2001 (as amended). Section 3 (1) of the Law establishes the system of democratically elected Local Government in the State. However, section 4 (1) of the Law recognizes 33 Local Government Councils and 35 Local Council Development Areas (section 4 (1) of the Local Government Law). Local Council Development Areas were created by the Government of Oyo State in the year 2016 through the amendment of the Local Government Law, 2001 by the Local Government (Further Amendment) Law 2016.

\section{Composition of Local Government Council}

In Oyo State and in all States of Nigeria, each Local Government Council comprises of executive and legislative arms. These arms are established under the Local Government Law, 2001 (as amended) of Oyo State. The executive arm consists of elected and non-elected officers. The elected officers are the Chairman and Vice-Chairman. The offices of the Chairman and Vice-Chairman are established under section 14 of the Local Government Law, 2001 of Oyo State, and they are contested for. Section 18 of the law provides that the office of the Chairman and Vice Chairman must be subject to elections and no Chairman can 
contest for elections without a Vice Chairman (section 18 (1).

The non-elected officers are Supervisory Councillors and Secretary to the Council. The Secretary (section 50 (1) and Supervisory Councillors are appointed by the Chairman. However, the appointment of Supervisory Councillors is subject to the confirmation of the Council (section 47 (2). Section 47 (1) of the Local Government Law provides that there shall be not less than 3 and not more than 5 offices of Supervisory Councillors of the Local Government. Supervisory Councillors are assigned responsibilities by the Chairman including administration of the Departments of the Local Government (section 24 (2). The duties of the Secretary include coordinating the activities of all departments of the Local Government; servicing the meetings of the Chairman and the Supervisory Councillors wherever necessary; interact with the Councillors; keep the record of the Local Government; perform other duties as may be assigned to him from time to time by the Chairman of the Local Government (section 51).

In running the affairs of the Local Government, the executive arm is assisted by career officers, the Head of Local Government Administration and directors of various departments in the Local Government. The Chairman presides over meetings with the members of the executive (section 24 (3). He assigns to the Vice-Chairman specific responsibilities in respect of the business of the Local Government including membership of the Security Committee (section 24 (1). In addition, the Chairman assigns to the Supervisory Councillors, responsibilities for the business of the Local Government including administration of any Department of the Local Government (section 24 (2).

The legislative arm comprises of the Councillors and they form the legislative Council (section 33 (1). Councillors are elected into office. Section 27 of the Local Government Law provides that a Councillor must be elected from every ward in a Local Government Area. In the Legislative Council, there is a Leader and a Deputy Leader who are elected by the Councillors of the Local Government from among them (section 34 (1). Functions of the Council include approving the budget of the Local Government (section 42 (3), passing laws known as bye-laws which are assented to by the Chairman (section 41 (4). However, where the Chairman withholds his assent, the bye-law can be passed by two thirds majority of the Council and the assent of the Chairman shall not be required (section 46 (6). The Council also has the power to summon anyone to appear before it and explain issues concerning the Local Government (section 42 (4).

With respect to elections into Local Government Councils, section 7 (4) of the Constitution provides that the Government of a State must ensure that every person who is entitled to vote or be voted for at an election to House of Assembly, shall have the right to vote or be voted for at an election to a Local Government Council. Thus, a combination of section 7 (1) and section 7 (4) of the Constitution gives the State Government the power to conduct elections into the executive and legislative arms of the Local Government Councils. The law governing Local Government election is the State Independent Electoral Commission 
Law 2000 (as amended) of Oyo State. Section 3 of the Law established the State Independent Electoral Commission of Oyo State and section 5 gives it power to conduct, organize and supervise elections into all Local Governments Councils in Oyo State.

\section{Sources of Revenue of Local Government Councils}

In Oyo State, Local Government Councils receive revenue from external and internal sources. The external sources are allocations from the federation account, State Government, grants and loans. However, the main sources of external revenue are from the federation and State Government accounts. The Internal source is the internally generated revenue of the Local Government Council derived from the functions they perform.

In Nigeria, the three tiers of government (that is, Federal, State and Local Governments) are entitled to revenue from the federation account. Section 162 (3) of the Constitution provides that any amount standing to the credit of the Federation Account shall be distributed among the Federal and State Governments and the Local Government Councils in each State on such terms and in such manner as may be prescribed by the National Assembly. The National Assembly determines the sharing formular of the revenue (section 162 (2) of the Constitution of Nigeria).

Under the Constitution of Nigeria, Local Government Councils are entitled to receive revenue from the federation account and the State Government. Section 7 (6) of the Constitution provides that (a) the National Assembly shall make provisions for statutory allocation of public revenue to Local Government Councils in the Federation; and (b) the House of Assembly of a State shall make provisions for statutory allocation of public revenue to Local Government Councils within the State. To receive this revenue, the Constitution mandates each State to maintain a special account called "State Joint Local Government Account" into which is paid all allocations to the Local Government Councils of the State from the federation account and from the Government of the State (section 162 (6) of the Local Government Law, 2001 of Oyo State). In Oyo State, the State Government created the State Joint Local Government Account under section 8 (1) of the Local Government Law (section 3 of the State Joint Local Government Account (Distribution) Law, 2002 (as amended).

The State Government receives the revenue from the federation account into the account on behalf of the Local Government Councils. Section 162 (5) of the Constitution provides that the amount standing to the credit of Local Government Councils from the federation account is allocated to the State for the benefit of their Local Government Councils as prescribed by the National Assembly (section 162 (5) of the Constitution of Nigeria). This means that the State Government receives the revenue on behalf and for the benefit of the Local Government Councils in the State. In the case of Attorney General of the Federation vs Attorney General of Abia State and Others, the Supreme Court of Nigeria held 
that the revenue allocated to Local Governments is the property of the Local Governments and not a joint property of the State Government and the Local Governments. Similarly, in the case of Attorney General of Plateau State vs Goyol and Ors, the court held that although State Governments have power to superintend the funds accruing to the Local Governments, they do not have the liberty to misapply such funds.

After receiving the revenue into the State Joint Local Government Account, the State Government is under an obligation to distribute it among the various Local Government Councils in the State. Section 162 (8) of the Constitution provides that the amount standing to the credit of Local Government Councils of a State shall be distributed among the Local Government Councils of that State on such terms and in such manner as may be prescribed by the House of Assembly of the State.

Furthermore, statutorily, Local Government Councils are to receive revenue from the State Government. In addition, section 162 (7) of the Constitution provides that each State must give Local Government Councils in its area of jurisdiction such proportion of its total revenue on the terms and in the manner prescribed by the National Assembly. This revenue is in addition to the revenue from the federation account and must be paid into the State Joint Local Government Account Section 4 (1) of the Allocation of Revenue (Federation Account, Etc.). Act provides that in addition to the allocation made from the Federation Account to Local Government Councils, there shall be paid by each State in the Federation to the State Joint Local Government Account in each quarter of the financial year, a sum representing 10 per cent of the internally-generated revenue for that quarter of the State concerned. Section 4 (2) of the Act provides that the ten percent revenue must be distributed among the Local Governments in that State on such terms and manner prescribed by the State House of Assembly.

It is however, unfortunate that in Oyo State, rather than give Local Government Councils $10 \%$ out of the revenue of the State, Oyo State Government took over some functions of Local Government Councils they yield substantial internal revenue and the revenue gotten from these sources are paid into the account of the State. It is out of this revenue, that the State gives $10 \%$ to the Local Government Councils in the State. This is backed by the Local Government Law, 2001 of Oyo State. Section 7 of the Law provides that the State Government shall remit to all Local Governments, ten percent (10\%) of the internally generated revenue accruing to the State Government's coffer from the Local Governments. This provision is a stylish way of avoiding the statutory duty of the State to give Local Governments Councils out of the revenue of the State, and a manipulative way of complying with the provisions of section 4 (1) of the Allocation of Revenue (Federation Account, Etc.) Act which mandates each State Government in Nigeria to give $10 \%$ of its revenue to Local Government Councils in its State. Oyo State Government craftily took over some functions of Local Government Councils that are good sources of internal revenue and gives them $10 \%$ of it, 
making it appear as if they are complying with the provisions of section 4 (1) of the Allocation of Revenue (Federation Account, Etc.) Act.

This unconstitutional act of the State Government has gone on for some years, due to the fact that caretaker committees have been appointed by the State Governor to administer Local Government Councils in Oyo State, instead of elected Local Government Councils as stated in section 7 (1) of the Constitution.

Some of the sources of internally generated revenue of Local Government Councils taken over by Oyo State Government are collection of fees for out-door adverts and motor park taxes. Collection of fees for out-door advertisements Constitution of the Federal Republic of Nigeria, (Paragraph 1 (k) (i) of the Fourth Schedule to the Constitution of Nigeria) and maintenance of motor parks (Paragraph 1 (e) of the Fourth Schedule to the Constitution of Nigeria) are the exclusive functions of Local Government Councils as stated in Paragraph 1 of the Fourth Schedule to the Constitution.

In order to take over out-door adverts, Oyo State Government established the Signage and Advertisement Agency in the year 2012 under section 3 of the Signage and Advertisement Agency Law, 2012. Functions of the Agency include (a) control outdoor structures to be used for signage and advertisements; (b) issue licenses and permits for the construction and placement of outdoor structures in any part of the State (section 5 (1) of the Signage and Advertisement Agency Law, 2012). This Agency collects the fees for all outdoor advertisements in Oyo State.

Similarly, in May 2019, the State Government proscribed the National Union of Road Transport Workers (NURTW) and took over all motor parks in the State and collected taxes (PM News, 31 May 2019). In February 2020, the State Government appointed park managers to administer the parks and collect taxes in order to boost the State's internally generated revenue (Vanguard News, 14 February 2020).

\section{Internally Generated Revenue of Local Government Councils}

Internally generated revenue is the revenue that Local Government Councils generate within their jurisdictions (Olusola 2011). These include taxes, rates, fees and fines deprived from the performance of the functions of Local Government Councils stated in Paragraph 1 (b)-(k) of the Fourth Schedule to the Constitution (section 7 (5) of the Constitution of Nigeria). These are (b) rates for radio and television licences; (c) rates for use of cemeteries, burial grounds and homes for the destitute or infirm; (d) licensing fees for bicycles, trucks (other than mechanically propelled trucks), canoes, wheel barrows and carts; (e) taxes and fees for slaughter houses, slaughter slabs, markets, motor parks and public conveniences; ( $f$ ) fees for parks, garden, open spaces or such public facilities; (g) fees for naming of street and numbering of houses; (h) fees for use of public conveniences, sewage and refuse disposal; (i) registration fees of all births, deaths and 
marriages; $(j)$ rates from privately owned houses or tenements; and (k) licensing fees for (i) out-door advertising and hoarding, (ii) movement and keeping of pets of all description, (iii) shops and kiosks, (iv) restaurants, bakeries and other places for sale of food to the public, (v) laundries, and (vi) sale of liquor.

With this array of sources of internal revenue, it would be expected that Local Government Councils would generate adequate revenue, in addition, to the revenue from the federation account and State Government to effectively develop their areas, but this is not the situation in Oyo State. The Local Government Councils in Oyo State find it difficult to generate adequate internal revenue to meet up with their responsibilities and expenditures. They struggle to pay salaries of their employees and are unable to engage in meaningful infrastructural development. This is so because the State Government exercises control over the juicy sources of internally generated revenue of the Local Government Councils. The State Government takes the lion share and releases a meagre 10\% of the revenue to the Local Government Councils as stated in section 7 Local Government Law. The Councils are highly controlled and subordinated by the State Government. The State Government is simply milking the Local Government Councils in Oyo State, leaving them with low yielding sources of internally generated revenue to develop their localities.

The purpose of revenue is to meet current and capital expenditures of the Local Government Councils. For the rural based Councils, the bulk of capital expenditure is on agriculture, rural development and health services. One of the primary reasons for creation of Local Government system is for grassroot development. Its developmental initiatives should complement that of the Federal and State Governments. However, the extent to which a Local Government Council can go in accomplishing this goal depends largely on its revenue strength (Otu \& Anam 2019).

To effectively perform its functions, develop its local area and meet all its expenditures, a Local Government Council must put in place robust machinery that would enable it generate the requisite internal revenue to augment what it receives from the federation account (Coker et al., 2015). Without adequate internally generated revenue, Local Government Councils will be unable to appreciably develop their localities, and this will make citizens lose confidence in the government as an institution.

\section{Challenges Confronting Local Government Councils in Generating Internal Revenue}

Local Government Councils are confronted with some challenges which have hindered their effectiveness. These challenges have put pressure on Local Governments in their attempt to perform their constitutionally assigned responsibilities. These challenges are examined below.

\section{1) Inability to Enact Bye-Laws}

One of the main problems of internal revenue generation is the inability of 
Local Government Councils to enact and effectively enforce bye-laws, which could enhance their revenue generation (Coker et al., 2015). This is as a result of the appointment of caretaker committees by State Government to administer Local Government Councils in Oyo State. Bye-laws are enacted by elected Local Government Legislative Councils (section 41 (4) of the Local Government Law), which consist of Councillors (section 33 (1) of the Local Government Law). These laws cannot be made by caretaker committees because they are not elected into office. Therefore, they cannot sit as legislative Councils of the Local Government Councils. Thus, the Councils are unable to generate revenue fees which may emanate from such laws and fines for a violation of the laws. Appointment of caretaker committees had also created an opportunity for the State Government to interfere with the internally generated revenue of the Local Government Councils.

2) Take Over of High Yielding Sources of Internally Generated Revenue by the State Government

Oyo State Government had taken over some of the high yielding sources of internally generated revenue of Local Government Councils. For example, the State Government has taken over the motor parks and appointed park managers to collect taxes which are paid into the coffers of the State Government. In addition, the State Government had taken over signage (advertisement on bill boards) which is a high yielding source of internal revenue for Local Government Councils. These take-overs have greatly affected the revenue generation of Local Government Councils in Oyo State and their performances.

3) Ten Percent Remittance to Local Government Councils from Internally Generated Revenue

Section 7 of the Local Government Law 2001 (as amended) of Oyo State provides that the State Government shall remit to all Local Governments ten percent of the internally generated revenue accruing to the State Government's coffer from Local Governments. This provision gives State Government the power to receive internally generated revenue from Local Government Councils and only give them ten percent of it. This is a very unfair provision because it deprives Local Government Councils of their internally generated revenue and only give them a meagre ten percent out of it. The State Government hides under this provision claiming to give Local Government Councils ten percent of its revenue as required by section 4 of the section 4 (1) of the Allocation of Revenue (Federation Account, Etc.) Act whereas in actual fact they are milking the Local Government Councils' internal revenue and giving them a little fraction of it.

This provision contradicts section 162 (7) of the Constitution which provides that each State shall pay to Local Government Councils in its area of jurisdiction such proportion of its total revenue on such terms and in such manner as may be prescribed by the National Assembly. State Governments are expected to pay ten percent out of their revenue and not to compel Local Government Councils to pay their internally generated revenue into State coffer and then give them ten 
percent of the revenue which wholly belongs to the Local Government Councils. This has deprived the Councils of the much needed revenue and resulted in the slow pace of development of Local Government Areas in Oyo State. Since section 7 of the Local Government Law 2001 (as amended) of Oyo State is clearly unconstitutional and therefore null and void.

\section{4) Other Challenges}

Other challenges hindering Local Government Councils from realizing adequate internally generated revenue are leadership failure, lack of political will to address the corruption at the administrative and political cadre, embezzlement and misappropriation of revenue by political office holders in the Local Government Councils, fraud by revenue collectors, corruption (Danjuman \& Zakariyau 2012). To effectively harness revenue internally, there must be proper training of revenue collectors and a mechanism for preventing fraud.

\section{Conclusion}

Internally generated revenue is an independent and substantial source of revenue for Local Government Councils in Oyo State. Local Government Councils are however, unable to fully access all sources of internal revenue due to State Government's interference. The State Government has become a drain-pipe of the internally generated revenue of Local Government Councils because the revenue has become the purview of Oyo State Government. This has greatly reduced the financial base of Local Government Councils and significantly hampered their developmental efforts.

Local Governments have great potentials to become the most efficient tier of government if allowed to wholly harvest from all sources of internally generated revenue. This avenue of finance, if properly managed, has the capacity to enhance the developmental roles of Local Governments as well as provide a mechanism for realistic fiscal projections. Also, it will minimize Local Government's dependence on revenue from federation account.

It is therefore expedient that Local Government Councils in Oyo State be allowed to receive and control all sources of internally generated revenue without any interference from the State Government. This will culminate in rapid development and give Local Governments the opportunity to explore various avenues for boosting their revenue base and debar fraud and other activities that may reduce adequate revenue generation.

\section{Recommendations}

Oyo State Government should stop meddling in the revenue generating functions of Local Government Councils and cease to collect internally generated revenue from Local Government Councils in the State. The National Assembly of Nigeria should expedite action on constitutional amendment to grant Local Government Councils full autonomy.

Local Governments should strive towards improving their internally generat- 
ed revenue base and instil transparency and accountability in their management structure. They should explore viable alternative sources of Internal Revenue in order to enhance their revenue base. In addition, Local Government Councils should block all sources of financial leakages. All sources of collectable fees, fines and taxes should be well harnessed and appropriate instruments and procedures fashioned out to achieve their effective collection and mobilization. Strategies should include adequate supervision and inspection technique to monitor revenue collection and ensure proper accountability. Revenue generation officers should be meritoriously recruited, trained and monitored for efficient performance of their duties. Regular training workshops should be organized for revenue officers in order to improve their expertise.

Finally, there should be staff motivation as incentives to revenue collectors which will wade off diversion of internally generated revenue. They should be encouraged so that they can put in their maximum services.

\section{Conflicts of Interest}

The author declares no conflicts of interest regarding the publication of this paper.

\section{References}

Allocation of Revenue (Federation Account etc.) Act Cap. A15 Laws of the Federation of Nigeria 2004.

Attorney General of Plateau State vs Goyol and Ors (2007) 16 NWLR Pt. 1059, p. 57.

Attorney General of the Federation vs Attorney General of Abia State and Others (2002) WRN 1, p. 96.

Ayogu, G. I. et al. (2019). Local Government Internally Generated Revenue and Projects Execution in Enugu State, 2007-2015. Account and Financial Management Journal, 4, 1870-1882.

Coker, M. A. et al. (2015). Challenges of Expanding Internally Generated Revenue in Local Government Council Areas in Nigeria. Journal of Sustainable Development, 8, 79-88. https://doi.org/10.5539/jsd.v8n9p79

Constitution of the Federal Republic of Nigeria Cap. C30 Laws of the Federation of Nigeria 2004.

Danjuman, A., \& Zakariyau, Y. K. (2012). Developing Alternative Sources of Funding Local Governments in Nigeria during Period of Global Economic Recession. Journal of Business and Management, 2, 41-45. https://doi.org/10.9790/487X-0234145

Local Government Law, 2001 (as amended) of Oyo State.

Olusola, O. O. (2011). Boosting Internally Generated Revenue of Local Governments in Ogun State, Nigeria (A Study of Selected Local Governments in Ogun State). European Journal of Humanities and Social Sciences, 8, 336-348.

Otu, J. E., \& Anam, B. E. (2019). Internally Generated Revenue and Local Government Performance in Nigeria: Implications for Rural Development. International Journal of Development Strategies in Humanities, Management and Social Sciences, 9, 112-113.

PM News, 31 May 2019. Oyo State Government Proscribes NURTW, Takes over All Motor Parks. 
https://www.pmnewsnigeria.com/2019/05/31/oyo-state-govt-proscribes-nurtw-takes-o ver-all-motor-parks

Samuel, O. O. (2016). Local Government Autonomy as an Imperative for True Federalism in Nigeria. Journal of Good Governance and Sustainable Development in Africa, 3, 85-90.

Signage and Advertisement Agency Law, 2012 of Oyo State.

State Independent Electoral Commission Law 2000 (as amended) Cap. 154 Laws of Oyo State, 2000.

Vanguard News, 14 February 2020. Oyo Government to Inaugurate Park Managers to Boost IGR.

https://www.vanguardngr.com/2020/02/oyo-govt-to-inaugurate-park-managers-to-boo $\underline{\text { st-igr }}$ 